he warmly supported the various scientific activities which grew up in connexion with it.

The Department of Antiquities has always formed a part of the same Ministry, and in its work and its responsibilities Garstin always took a keen interest. As soon as the Aswan Dam was decided upon, entailing the partial submergence of the island and temples of Philæ, he took measures for the complete underpinning of all parts of the buildings which were not founded on rock; and later, when the raising of the Dam became necessary, he obtained the allocation of a considerable sum for the execution of an archæological survey of that portion of the Nile Valley which would be submerged. The present Museum at Cairo is also due to his efforts to house safely the ever-increasing collections of Egypt's ancient civilisation.

A keen sportsman, the wild fauna of the Sudan strongly attracted Sir William Garstin; from its inception he strongly supported and took an active interest in the Zoological Gardens at Giza.

\section{H. G. L.}

WE are indebted to Science of November 28 for the following details of the life and work of Prof. W. A. Locy, professor of zoology in Northwestern University, Illinois, who died on October 9 at the age of sixtyseven. William Albert Locy was born at Troy, Michigan, of Dutch ancestry, and received his early training in the University of Michigan. During the year $1884-85$ he held a fellowship at Harvard, where he completed an embryological investigation on "The Development of Agelena naevia." In I887 he went as professor of biology to Lake Forest University, where he remained nine years. During this period he published important papers on the embryonic development of the elasmobranchs, the derivation of the pineal eye, and the structure and development of the vertebrate head. In 1896 Locy succeeded Prof. E. G. Conklin at Northwestern University, where he remained until his death. His work there had two aspects; one, the developmental history of the sense organs, to some extent a continuation of his earlier researches ; the other, the history of biological science. In I908 he published a collection of historical portraits entitled "Biology and its Makers," which has since been translated into German, while in 19r8 he produced "Main Currents in Zoology," and at the time of his death he was completing another work, "The Rise of Biology." The significance of his work on the history of science was recognised by his election as the first president of the History of Science Section of the American Association. He was also president in 1915 of the American Society of Zoologists.

$W_{E}$ regret to record the death, at the age of sixtyseven, of Prof. J. Bergonié, professor at the clinic for medical electricity and biological physics in the University of Bordeaux. Prof. Bergonié was chiefly known for his work on electro-therapy. He was the author of numerous papers, and was for many years editor of the Archives d'Électricité médicale, in which journal most of his original publications appeared. Among the most important of his original contributions to medicine we may mention "Contributions à l'étude du phénomène physique du muscle" and "Physique du physio- logiste et de l'étudiant en médecine" (I892). Prof. Bergonié invented an ingenious device for localising metallic foreign bodies in the human subject, which was used to some extent in the War. He also invented an apparatus designed to treat the condition of obesity. $\mathrm{He}$ died as a result of injuries associated with X-rays and radium. During the last few years he had been actively at work upon the anti-cancer centre at the Hôpital St. André, Bordeaux. He twice received the gold medal of the Carnegie Foundation.

IN the issue of the Physikalische Zeitschrift for November 15, Prof. E. Warburg gives a sympathetic account of the life and scientific work of his former assistant and colleague, Karl Richard von Koch, who died a short time ago after having resigned the professorship of physics at the Stuttgart Technical School in Igrg owing to heart trouble. Prof. Koch was born at Stettin in 1852 , and after studying at Bonn, Freiburg and Göttingen, graduated Ph.D. at Freiburg in 1875 . While librarian there he commenced research in physics under Warburg, and was appointed lecturer in physics in $\mathrm{I} 88 \mathrm{I}$ and extra professor in $\mathrm{I} 886$. In $\mathrm{I} 888$ he became professor at the Aachen, and in I89I at the Stuttgart Technical School. Here he designed the new Physical Institute, opened in I910, which has since served as a model of what such an institute should be. His scientific work lay mainly in the direction of improving methods of measurement, especially in elasticity, but he took great interest in the application of physical principles to practical problems and to natural phenomena. His best-known researches are probably those on the elasticity of metals at high temperatures, on the determination of gravity, and on the auroræ.

WE regret to announce the following deaths:

Prof. S. A. Beach, professor of agriculture at Iowa State College, who was known for his work on apple growing and whose name is included in the list of honorary and corresponding members of the Royal Horticultural Society, on November 2, aged sixtyfour.

Mr. Alfred H. Brooks, for twenty years chief of the Alaskan Division of the United States Geological Survey, on November 2I, aged fifty-three.

Dr. E. Hedinger, professor of pathological anatomy and histology in the University of Zurich, and formerly of the University of Basle, who, in I9I4, undertook a special mission to South Africa to investigate trypanosomiasis in cattle, on December 24, aged forty-eight.

Dr. Theodore Hough, dean of the medical department and for seventeen years professor of physiology in the University of Virginia, who worked on the factors regulating breathing and on related subjects, aged fifty-nine.

Mr. A. H. Savage Landor, well known as a traveller and explorer in Tibet and China and also in South America, on December 26.

Mr. F. G. Newton, director of the Egypt Exploration Society's excavations in Egypt, on December 25, aged forty-six.

Dr. B. R. G. Russell, of the Imperial Cancer Research Fund, who made noteworthy contributions to our knowledge of tumour transplantation and of the respiration and carbohydrate metabolism of normal and cancerous tissue, on December 22, aged forty-four. 